\title{
To which genus does the enigmatic Peninsular Malaysian Chirita elata (Gesneriaceae) belong?
}

\author{
A.R. Rafidah ${ }^{1,2}$, R. Kiew ${ }^{1}$, N.W. Haron ${ }^{2}$
}

Key words

Chirita

Codonoboea

Didissandra

Peninsular Malaysia

stamens

stigma
Abstract The anomalous Chirita elata proves to belong to Codonoboea (Gesneriaceae), necessitating the new combination Codonoboea elata.

Published on 23 February 2011

\section{INTRODUCTION}

In Peninsular Malaysia, the genus Chirita Buch.-Ham. ex Don (Gesneriaceae) includes nine species (Wood 1974). Except for C. elata, all Chirita species in Peninsular Malaysia are restricted to limestone habitats (Henderson 1939). In contrast, $C$. elata grows in lower montane forest on granite-derived soils. When establishing the species, Ridley (1896) was uncertain of its generic placement and noted "it has more of the habit of Didissandra of the $D$. frutescens group, but has two fullydeveloped stamens" and again in 1905 he noted that it was "a species very unlike the rest of the genus but it is difficult to place it anywhere else".

Wood (1974) in his revision of Chirita placed C. elata in sect. Microchirita, to which all but one Malaysian Chirita species belong. However, it is very different from the other species in this section by a combination of its habit (it is a tall, bushy, perennial herb), its inflorescence (a slender, 1- or 2-branched ebracteate cyme with its peduncle not joined to the petiole), flower colour (deep reddish purple, which Ridley (1905) described as claretcoloured), its nectary (ring-like and c. $2.5 \mathrm{~mm}$ tall), and its fruits (orthocarpic, i.e. aligned straight with the pedicel). Species in sect. Microchirita are annual plants, with epiphyllous, crest-like inflorescences, or if they have cymose inflorescences the inflorescences develop from a cup-like bract, where the peduncle is adnate to the petiole, the flowers are white, cream, orange, pale blue to (rarely) deep violet-purple, the nectary is very small only $0.2-0.6 \mathrm{~mm}$ tall, and the fruits are plagiocarpic (i.e. held perpendicular to the pedicel). Although it resembles $C$. lacunosa (Hook.f.) B.L.Burtt (also a Malaysian species but which belongs to sect. Chirita) in its cymose inflorescences and deep purple flowers, it is different in its deeply divided calyx (species in sect. Chirita have a tubular calyx) as well as in habit and anther and stigma characters.

This raises the question of whether $C$. elata is a species of Chirita at all. Chirita belongs to a group of Old World genera, Codonoboea Ridl., Didissandra C.B.Clarke, Didymocarpus Wall.,

\footnotetext{
${ }^{1}$ Forest Research Institute Malaysia, 52109 Kepong, Selangor, Malaysia; corresponding author e-mail: ruth@frim.gov.my.

2 Institute of Biological Sciences, Faculty of Science, University of Malaya, 50603 Kuala Lumpur, Malaysia.
}

Henckelia Spreng., and Ridleyandra A.Weber \& B.L.Burtt that have long narrow capsules and usually have trumpet-shaped flowers. It has been distinguished from these five genera by a single character, the stigma that is described as bilobed (Fig. 1c). Burtt (1954) agreed with Brown (1839) that this stigma is derived from the lower lip of the stigma (the upper lip does not expand) that is thin and lamellate and often divided and appearing bilobed. This contrasts with Codonoboea, Didissandra (Fig. 1b), Didymocarpus and Henckelia that have stigmas that may be rounded, capitate or peltate (Kiew 1992, Weber 2004). The stigma of Ridleyandra develops from the lower lobe but is not bilobed (Weber \& Burtt 1998b). Examination of fresh material clearly shows that $C$. elata has a large peltate (not bilobed) stigma c. $1 \mathrm{~mm}$ across (Fig. 1a), so that it clearly cannot belong to Chirita. So among the five genera, to which does it belong?

In possessing flowers with two stamens and a very slender orthocarpic capsule that splits on both sides, it is distinct from Ridleyandra species that have flowers with four stamens and a thick-walled, plagiocarpic capsule that splits only on the upper side. Species of Codonoboea and Henckelia, although their flowers have two stamens, are distinct because the fruit splits neatly along the upper side and is plagiocarpic. Chirita elata and species of Didissandra and Didymocarpus are similar in the orthocarpic fruits. The fundamental difference between Didissandra and Didymocarpus is the way that the capsule splits. In Didymocarpus, it splits completely from top to bottom along both sides into two valves, while in Didissandra it splits irregularly (i.e. not completely from top to bottom) and eventually disintegrates into several threads that correspond to the ribs (sclerenchyma bundles) in the fruit wall (Weber \& Burtt 1998a). Didissandra fruits are also more slender than those of Didymocarpus. Fruits of $C$. elata are also very slender (1-2 $\mathrm{mm}$ wide) and often appear not to dehisce until the fruit wall begins to disintegrate between the ribs, i.e. it has the Didissandra-type of fruit.

Species of Codonoboea, Didymocarpus and Henckelia always have two stamens but most Didissandra species have four - the reason that Ridley (1896) originally did not describe C. elata as a species of Didissandra. Now results from DNA analysis are available (Weber et al. in prep.), the position of $C$. elata is 

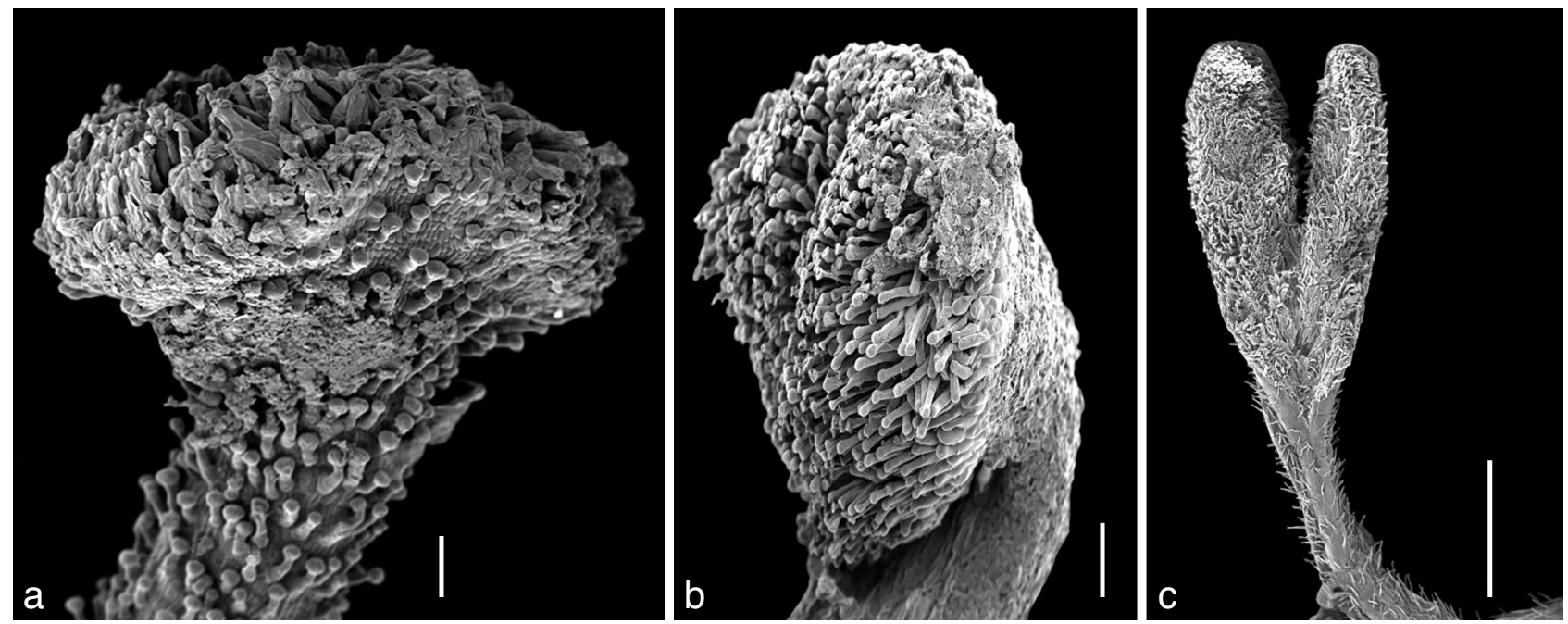

Fig. 1 a. Codonoboea elata peltate stigma; b. Didissandra frutescens peltate stigma; c. Chirita caliginosa bilobed stigma. - Scale bars: a, b = $100 \mu$; $\mathrm{c}=1 \mathrm{~mm}$.

resolved because it clusters together with other Peninsular Malaysian species of Codonoboea, a monophyletic genus (formerly included in Henckelia). While C. elata conforms to the diandrous character of Codonoboea, it expands the circumscription of this genus, which now includes species with extremely narrow capsules that are not strictly plagiotropic. The combination, together with a detailed description, is made below.

\section{Codonoboea elata (Ridl.) Rafidah, comb. nov.}

Basionym: Chirita elata Ridl., J. Linn. Soc., Bot. 23 (1896) 518; (1905) 57; (1923) 524; M.R.Hend. (1959) 349; D.Wood (1974) 189. - Type: Ridley 2911 (lectotype BM; isolectotype SING), Peninsular Malaysia, Perak, Maxwell's Hill (Bukit Larut).

Bushy, caulescent, perennial herb, branching from the base. Stems green, quadrangular, up to $50 \mathrm{~cm}$ tall, $6-8 \mathrm{~mm}$ diam, becoming woody, glabrous, hairy or bristly; internodes swollen, up to $7.5 \mathrm{~cm}$ long, hispid at the nodes with red-brown reflexed hairs. Leaves opposite, decussate; petioles green, sometimes maroon, up to $5.5 \mathrm{~cm}$ long; lamina ovate, sometimes elliptic or broadly elliptic, (5-)10-15.6 by (2.5-)4-8 cm, pale green to yellowish above, whitish green beneath, fleshy in life, chartaceous when dry, eglandular hairy above, predominantly glandular hairy on the veins of the lower surface, base rounded to slightly decurrent or cuneate, sometimes unequal, margin serrulate, apex acute or acuminate; midrib sunken above, prominent beneath, lateral veins $10-20$ pairs, intercostal veins scalariform. Inflorescences cymose, axillary, 2 per axil, each with up to 6 flowers; peduncles, bracts and pedicels green or maroon with reflexed red-brown hairs; peduncles slender, 2-6 $\mathrm{cm}$ long, not fused to the petiole; bracts paired, opposite, free, narrowly triangular, c. $3 \mathrm{~mm}$ long; pedicels $5-18 \mathrm{~mm}$ long. Flowers: calyx green, $8-10$ by $4-5 \mathrm{~mm}, 5$-lobed, divided to the base, lobes narrowly triangular, margin ciliate, outer surface eglandular hairy; corolla reddish purple or dark purple, narrowly infundibular, lobes darker red than the corolla tube, throat dark yellow, outside slightly hairy, tube up to $4 \mathrm{~cm}$ long, narrow in the lower part, slightly inflated, c. $1.5 \mathrm{~cm}$ wide across the mouth, lobes $5,5-6$ by $2-4 \mathrm{~mm}$; stamens 2 , inserted $12-15 \mathrm{~mm}$ from the base of the corolla, filaments white, $9-12 \mathrm{~mm}$ long, curved, anthers white, anther-thecae divergent, 2-3 mm long, fused face-to-face; staminodes 3 , white, inserted c. $6 \mathrm{~mm}$ from the base of the corolla tube, c. $2 \mathrm{~mm}$ long; nectary very pale yellow, a shallowly lobed ring, 2-2.5 mm deep; pistil pale green to cream, densely pubescent with predominantly eglandular reddish hairs, ovary c. $2.5 \mathrm{~cm}$ long, $0.5 \mathrm{~mm}$ wide at the base, style cream, 1-1.4 cm long, narrowing to $0.1 \mathrm{~mm}$ below the flattened stigma, stigma red or maroon, peltate, entire, up to $1 \mathrm{~mm}$ diam, papillose, ovules cream, less than $1 \mathrm{~mm}$ long, c. $2 \mathrm{~mm}$ diam. Capsules green, cylindrical, very slender, $6.5-7 \mathrm{~cm}$ long, 1-2 mm wide, red hairy, often appearing not to dehisce until the fruit wall begins to disintegrate between the ribs; calyx persistent, green. Seeds (immature) white, many, outer surface striated.

Ecology - Lower montane forest, in deep shade often on earth slopes above streams, at 700-1000 m altitude.

Specimens examined. PERAK, Bukit Larut FR, Burkill SFN 12990 (SING), Curtis 2038 (SING), Curtis s.n. (SING), Haniff SFN 2353 (SING), Sinclair SFN 38713 (SING), Spare 2052 (SING), Wray 2038 (SING), Wray 2985 (SING), Kiew RK 5318 (KEP), Rafidah FRI 64321 (KEP); Gunung Bubu, Syahida FRI 59486 (KEP).

Note - Recent collections made under the Flora of Peninsular Malaysia Project have discovered that this species is found in a similar habitat on the nearby hill of Gunung Bubu, also in Perak.

Acknowledgements This research was carried out as part of the Flora of Peninsular Malaysia Project (Project no. 01-04-01-0000 Khas) at the Forest Research Institute Malaysia (FRIM), Kepong, funded by the Ministry of Science, Technology and Innovation (MOSTI). In addition, the first author is indebted to the following for financial support: the Systematic Studies of Selected Taxa of Plants Project (Erycibe (Convolvulaceae), Chirita, Henckelia section Boeopsis, Loxocarpus and Salicini (Gesneriaceae) and Utricularia (Lentibulariaceae) in Peninsular Malaysia (GPP-TFBC-1208-001) at FRIM and funded by MOSTI, to the IPPP grant (Project no. PS171/2008B) at University of Malaya, Kuala Lumpur; and to Dr Michael Moeller and Alan Forrest, Royal Botanic Gardens Edinburgh, for the DNA analysis. We are grateful to the curators of the herbaria at Singapore Botanic Gardens and the University of Malaya for permission to examine specimens in their care. We also thank Mr. Roslee Halip for assistance in the SEM technique. Also thanks to Dr. Saw, L.G. and Dr. Richard Chung for editing the manuscript.

\section{REFERENCES}

Brown R. 1839 ('1840’). On Cyrtandreae. In: Bennett JJ, Plantae Javanicae Rariores. London, Richard \& John Taylor.

Burtt BL. 1954. Studies in the Gesneriaceae of the Old World. General introduction. Notes Royal Botanic Garden Edinburgh 21: 185-192.

Henderson MR. 1939. The flora of the limestone hills of the Malay Peninsula. Journal Straits Branch Royal Asiatic Society 17: 13-87.

Henderson MR. 1959. Gesneriaceae. Malayan wild flowers. Dicotyledons. Malayan Nature Society, Malaysia: 337-363.

Kiew R. 1992. Five new species of Didymocarpus (Gesneriaceae) from

Peninsular Malaysia. Gardens' Bulletin Singapore 44: 23-42. 
Rafidah AR. 2010. Revision of Chirita (Gesneriaceae) for Peninsular Malaysia. Unpublished MSc thesis, University of Malaya, Kuala Lumpur, Malaysia.

Ridley HN. 1896. Cyrtandraceae Malayenses. Journal of the Linnean Society 23: $497-528$.

Ridley HN. 1905. The Gesneraceae of the Malay Peninsula. Journal Straits Branch Asiatic Society 43: 1-92.

Ridley HN. 1923. Gesneriaceae. Flora of Malay Peninsula 2: 495-524.

Weber A. 2004. Gesneriaceae. In: Kubitzki K, Kadereit J, Families and genera of vascular plants. Vol. 7. Flowering plants. Dicotyledons. Lamiales (except Acanthaceae including Avicenniaceae): 63-158. Berlin etc., Springer.
Weber A, Burtt BL. 1998a ('1997'). Didissandra: redefinition and partition of an artificial genus of Gesneriaceae. Beitrage zur Biologie der Pflanzen 70, 2-3: 153-177.

Weber A, Burtt BL. 1998b. Revision of the genus Ridleyandra (Gesneriaceae). Beitrage zur Biologie der Pflanzen 70, 2-3: 225-273.

Weber A, Middleton DJ, Forrest A, Kiew R, Lim CL, Rafidah AR, Yao TL, Möller M. In prep. Molecular systematics and remodeling of Chirita and associated genera (Gesneriaceae).

Wood D. 1974. A revision of Chirita (Gesneriaceae). Notes Royal Botanic Garden Edinburgh 33: 123-205. 